\title{
SÁNCHEZ ZAPATERO, J. y MARTÍN ESCRIBÀ, À. (2017). Continuará... Sagas literarias en el género negro y policiaco español. Barcelona: Alrevés, 217 pp., ISBN: 978-84-16328-88-8.
}

Traspasar el umbral de una ficción serial implica un compromiso que, dependiendo de la extensión de la misma y de si se encuentra finalizada o no, puede llegar a ser de muy largo plazo. No obstante, esta especie de pacto no escrito suele compensar, ya que "leer una saga no es solo leer cada una de las novelas que la forman, sino también ir descubriendo de forma panorámica a los personajes que la integran" (32). Esto genera un sentimiento de familiaridad entre el lector y el universo ficcional, al que se sigue queriendo volver una y otra vez en busca de repetir lo que se experimentó por primera vez y de reencontrarse con esos personajes que pasan a convertirse en viejos amigos.

Si bien la serialidad está presente en muchos géneros literarios, en el caso de la ficción negra y policiaca es un rasgo esencial para comprenderla, una marca de género vinculada al mismo desde sus orígenes como parte de la literatura popular, cuyo formato de publicación se realizaba por entregas. Este es el objeto de estudio de Continuará..., un ensayo escrito por Javier Sánchez Zapatero y Àlex Martín Escribà, que pone su foco de atención en cómo se comporta este fenómeno en la narrativa española. El texto presenta una estructura dual, con una primera parte dedicada a la historia de las sagas en la que, a partir de un repaso a los clásicos de la ficción detectivesca desde una perspectiva universal, atendiendo a patrones repetitivos, tipos de personajes y escenarios, se establece una base para abordar el caso español y las peculiaridades de su desarrollo con respecto al resto de Europa. A través de tres etapas bien definidas, los autores muestran la evolución del género a lo largo del siglo XX y XXI: desde una situación inicial marcada por la ausencia total de tradición, en la que ocupa un lugar marginal, donde lo que proliferan son las parodias de los modelos extranjeros, hasta la actualidad en donde como consecuencia del boom editorial que experimenta, la etiqueta de "novela negra" empieza a perder sus rasgos definitorios al englobar tipos de obras muy diferentes como consecuencia de la tendencia a la hibridación con otras variantes literarias. En el camino entre ambos puntos, los autores desgranan las sagas clave en la creación de la variante española del género policiaco, destacando la presencia de, a grandes rasgos, dos vertientes de personajes investigadores: los 
pertenecientes a las fuerzas del orden, liderados por el jefe de Policía municipal Plinio -de Francisco García Pavón, y los detectives privados, representados por el gran mito de la novela negra española, Pepe Carvalho, creación de Manuel Vázquez Montalbán.

El estudio se completa con una parte más práctica, dedicada al análisis de tres paradigmas seriales iniciados en la década de 1990 que han sido seleccionados por los autores por considerarlos determinantes para entender esta tendencia en la literatura española. Aparte de dar cuenta de las similitudes y diferencias existentes entre ellos, el estudio ahonda en los aspectos definitorios de los mismos, concluyendo cada uno de ellos con una entrevista al autor en cuestión. Se trata de tres sagas protagonizadas por investigadores que en la actualidad siguen en activo y aún no han dado por finalizadas sus aventuras: el detective privado Ricardo Cupido, creación de Eugenio Fuentes, la inspectora Petra Delicado, de Alicia Giménez Barlett, y el guardia civil Rubén Bevilacqua, de Lorenzo Silva. Estos tres personajes, tan diferentes entre sí, ponen de relieve el amplio espectro que recoge el género negro en nuestro país: ya sea la idea romántica y caduca del solitario detective privado, la aceptación de los miembros de las fuerzas del orden como protectores de nuestra sociedad o la necesaria y progresiva incorporación de la mujer al panorama de la novela criminal en un rol activo.

Continuará... es, por tanto, un libro perfecto para todo aquel que quiera acercarse a la ficción policial y detectivesca española, cuyo carácter divulgativo lo hace accesible a cualquier tipo de lector, tanto al iniciado en el tema como al neófito. Además, cuenta con el sello de calidad de ser obra de dos expertos con una larga trayectoria investigadora en torno a esta materia, como son Sánchez Zapatero y Martín Escribà, promotores ellos mismos de una saga de congresos en torno al género negro que se celebran anualmente en la Universidad de Salamanca.

Ángela Palacios Martín

Universidad de Salamanca

angelapalaciosmartin@gmail.com 